Post-print of: Trees-Structure and Function, Volume 29, Issue 4, August 2015, Pages $1247-1257$

\title{
Low winter temperatures induce a disturbance of water relations in field olive
} trees

Álvaro López-Bernal ${ }^{1, *} \cdot$ Omar García-Tejera $^{1} \cdot$ Luca Testi $^{1} \cdot$ Francisco Orgaz $^{1} \cdot$ Francisco J. Villalobos $^{1,2}$

${ }^{1}$ Instituto de Agricultura Sostenible - CSIC Apartado 4084, 14080 Cordoba (Spain)

${ }^{2}$ Dep. Agronomia, Universidad de Cordoba, Apartado 3048, 14080 Cordoba (Spain)

"To whom correspondence should be addressed Tel.: +34 957499296, fax: +34 957499252, E-mail address: g42lobea@uco.es

\section{Author contribution statement}

AL, OG, LT, FO and FJV designed the experiments. AL and OG carried out the fieldwork. AL, OG, LT, FO and FJV analyzed the data and prepared the manuscript.

\section{Conflict of interest}

None.

\section{Key Message}

Low winter temperatures induce an increase in the soil-to-trunk hydraulic resistance of field-grown olive trees resulting in a significant disturbance of their water relations. 


\begin{abstract}
A disturbance of water relations in response to chilling have long been observed in potted plants growing under controlled conditions, but information is lacking for field plants. The aim of this study was to assess the effects of winter low temperatures on the water relations of mature olive trees. To this end, water potential, sap flux density, soil temperature and meteorological data were monitored in a hedgerow olive orchard near Córdoba, southern Spain, throughout two consecutive winters. Water stress symptoms were found in terms of midday $\Psi$ despite adequate water supply and low evaporative demand. These effects were associated with changes in the soil-to-trunk hydraulic resistance $\left(R_{\text {root }}\right)$, which increased by December-January to much higher values than those previously reported in the literature, particularly in the year of higher fruit load. The contribution of viscosity $(\eta)$ to the observed $R_{\text {root }}$ dynamics was almost negligible as deduced from measurements of soil temperature, so the high winter values of $R_{\text {root }}$ were likely to have originated from other causes such as reductions in membrane permeability and root growth. The findings of this work raise new major issues that deserve further research such as the impact of the winter water stress on stomatal conductance and photosynthesis rates in mature olive trees.
\end{abstract}

Keywords: chilling stress, hydraulic resistance, olive, water potential, water relations, viscosity. 


\section{Introduction}

The olive (Olea europaea L.) is an evergreen fruit tree species widely cultivated in the Mediterranean basin, whose climate is characterized by hot dry summers and cool wet winters. As the typical summer drought severely limits yield in traditional rainfed orchards and the water available for irrigated systems is scarce, extensive research has focused on the adaptation of olive trees to water limited conditions (Fernández et al. 1997; Moriana et al. 2003; Connor 2005; Tognetti et al. 2009; Boughalleb and Hajlaoui 2011; Torres-Ruiz et al. 2013). Scientific activity has led to the development of both irrigation scheduling techniques based on the actual water requirements (Orgaz et al. 2006; Testi et al. 2006), deficit irrigation strategies (Moriana et al. 2003; Iniesta et al. 2009) and plant based methods for a precise monitoring of water stress (Fernández and Cuevas 2010; López-Bernal et al. 2010; Fernández et al. 2011; López-Bernal et al. 2012). However, less attention has been paid to water relations beyond the dry season.

Plant responses to low temperatures similar to those induced by water stress have long been reported (Kramer 1940). In addition, a number of studies have also shown that sensitivity to the so-called 'chilling stress' differs among species and even among cultivars (Kramer 1942; Aroca et al. 2001; Bloom et al. 2004). Under chilling conditions, temporal imbalances between root water uptake and transpiration take place, resulting in shoot water deficits. These effects are attributed to increased hydraulic resistance of the water pathway from soil to shoots $(R)$ as water viscosity $(\eta)$ increases with decreasing temperatures (Yamamoto 1995; Hertel and Steudle 1997; Cochard et al. 2000). However, there is also a body of evidence suggesting that this phenomenon is the consequence of an increase in root hydraulic resistance $\left(R_{\text {root }}\right)$ originating in the radial pathway of water from the soil-root interface to the xylem (Running and Reid 1980; Ameglio et al. 1990; Wan et al. 2001).

Despite studies assessing the impact of chilling stress on the water relations of trees have been studied for decades (Kramer 1942; Running and Reid 1980; Pavel and Fereres 1998; Norisada et al. 2005), actual observations under natural conditions are still lacking to date. To our knowledge, all studies have been conducted in either lab conditions (e.g. Running and Reid 1980), growth chambers (e.g. Wan et al. 2001) or with plants growing outdoors that are exposed to localized warming or cooling (e.g. Norisada et al. 2005). Furthermore, the reported experiments have always been conducted with young seedlings growing in either pots or hydroponics. This might be inconvenient for extrapolating the results to mature field trees, as both architectural and anatomical root traits can be affected in those artificial conditions. In this 
regard, it is known that hydroponics can affect the development of root exodermis (Steudle 2000) and that both the morphology and physiology of root systems as well as root-to-shoot ratios are frequently altered in potted trees (Passioura 2006). Further uncertainties arise from the typical short duration of precedent experiments and the way in which trees were chilled. For instance, the chilling stress was frequently induced in previous studies by artificially decreasing the temperature of the soil or mineral solution, which contrasts with the fact that roots are exposed to higher temperatures than the canopy under field conditions. In the light of the above, the occurrence and extent of the chilling stress in mature trees growing in the field remain unknown.

The only studies characterizing the effects of chilling on water relations of olive trees are those conducted with one-year-old potted trees by Pavel and Fereres (1998) and Pérez-López et al. (2010). The former found reductions in both stomatal conductance and stem and leaf water potentials whereas they encountered increases in $R_{\text {root }}$ when trees were steadily exposed to soil temperatures below $6.4 \pm 0.5^{\circ} \mathrm{C}$. However, they did not observe the phenomenon under low night $\left(2.5 \pm 0.4\right.$ and $\left.5.2 \pm 0.4{ }^{\circ} \mathrm{C}\right)$ but ambient day $\left(16.2 \pm 3.2^{\circ} \mathrm{C}\right)$ soil temperatures. On the other hand, the study of Pérez-López et al. (2010) reported differences in sensitivity to soil chilling between six cultivars.

This work describes the effects of low temperatures in two consecutive winters on a mature hedgerow olive orchard in Southern Spain. The main goal of this work was to characterize the seasonal patterns of water relations of field olive trees from autumn to spring ascertaining whether the exposure to the low winter temperatures result in similar alterations to those previously observed in young potted plants under controlled conditions or not.

\section{Materials and methods}

\section{Experimental site}

The experiments were conducted in two consecutive winters (2011-2012 and 2012-2013) from November to April in an olive (cv. Arbequina) hedgerow orchard located at the CIFA Experimental Station, Córdoba, Spain $\left(37.8^{\circ} \mathrm{N}, 4.8^{\circ} \mathrm{W}, 110 \mathrm{~m}\right.$ altitude). The olive trees were planted in 1999 and they were renovated by pruning at ground level in 2008. Tree spacing was $3.5 \mathrm{~m} \times 1.5 \mathrm{~m}$. During the dry season (period spring-autumn), irrigation was applied with $2.3 \mathrm{~L} / \mathrm{h}$ drippers supplying enough water to keep maximum evapotranspiration, which was calculated according to the approach of Orgaz et al. (2006). The 
soil is a Typic Xerofluvent of sandy loam texture exceeding $1.5 \mathrm{~m}$ in depth, with upper drained soil water content limit of $0.23 \mathrm{~m}^{3} \mathrm{~m}^{-3}$ and lower soil water content limit of $0.07 \mathrm{~m}^{3} \mathrm{~m}^{-3}$ (Testi et al. 2004). Five trees in 2011-2012 and four in 2012-2013 were randomly selected for measurements, with 2011 being a year with high fruit load and 2012, one with low fruit load. During the experiment, the height of the canopy was $3 \pm 0.5 \mathrm{~m}$ and trees presented an average leaf area index of $1.2 \mathrm{~m}^{2} \mathrm{~m}^{-2}$ which was estimated from measurements of diffuse radiation interception performed with a Plant Canopy Analyzer (LAI-2000, Li-Cor, Lincoln, NE, USA). All the fruits of experimental trees were removed in late November before the first measurement date in both years.

\section{Measurements}

Measurements were performed on sunny days five times per season from late autumn to early spring. November 29, December 23, January 19, February 22 and March 22 in 2011-1012 season and November 28, December 22, January 29, February 15 and April 12 in 2012-2013 were the measurement dates.

Water potential $(\Psi)$ was determined using a pressure chamber (Soil Moisture Equipment Corp., Santa Barbara, CA, USA). Values of $\Psi$ were recorded at predawn and midday in 2011-2012 while for the following winter we included measurements at $1.5 \mathrm{~h}$ intervals from 1 hour before sunrise until noon. Four sun-exposed shoots from the canopy top (with 1-3 leaf pairs attached) were sampled per experimental tree in each measurement. In addition, $\Psi$ of non-transpiring shoots directly attached to the tree trunk or main branches $\left(\Psi_{\text {trunk }}\right)$ were measured at midday (four shoots per tree were covered with aluminum foil five hours before the measurements) in all the experimental trees of 2012-2013 and two of the five trees in 2011-2012.

Experimental trees were instrumented with sap flow sensors (one per tree, always in the trunk at a height of $40 \mathrm{~cm}$ from the soil and below a main branch) based on the compensated heat pulse method (Swanson and Whitfield 1981). The probes used were designed and produced in the IAS-CSIC laboratory in Córdoba, Spain and consist of a $4.8 \mathrm{~W}$ stainless steel heater of $2 \mathrm{~mm}$ diameter and two temperature probes of the same diameter located 10 and $5 \mathrm{~mm}$ down- and upstream of the heater, respectively (Testi and Villalobos 2009). Each temperature probe had four embedded Type E (chromel-constantan wire) thermocouple junctions, spaced $10 \mathrm{~mm}$ along the needle, that were sampled separately to obtain heatpulse velocities at 5, 15, 25 and $35 \mathrm{~mm}$ below the cambium at 15 -min intervals. Sensors were installed at a height of $40 \mathrm{~cm}$ from the soil, and the system was controlled by a datalogger (CR1000, Campbell 
Scientific Inc., Logan, UT, USA). Further details concerning both data processing and sap flow calculations are described in detail in Villalobos et al. (2013).

For the second winter (2012-2013) soil temperature was monitored with Type K (chromel-alumel) thermocouples. Temperature was recorded at 15-min intervals and the equipment was controlled by a datalogger (CR1000, Campbell Scientific Inc., Logan, UT, USA). Three thermocouples were installed at $75 \mathrm{~mm}$ depth around one of the experimental trees: one close to the tree trunk $(20 \mathrm{~cm}$ apart $)$, another in the middle point between trees in a row $(75 \mathrm{~cm}$ apart) and the last one in the central point of the alley between four trees. The averaged value was used to derive the seasonal course of root sap $\eta$ from a:

$$
\eta=\frac{1.9510^{8}}{T^{7}}
$$

where $T$ is the liquid temperature in $\mathrm{K}$ and $\eta$ is in $\mathrm{MPa} \mathrm{s}^{-1}$ (Roderick and Berry et al. 2001).

Meteorological data was recorded at 10-min intervals in an automated weather station placed $500 \mathrm{~m}$ from the orchard.

Determination of stomatal conductance

Midday values of canopy stomatal conductance $\left(G_{\mathrm{s}}, \mathrm{mol} \mathrm{m} \mathrm{m}^{-2}\right)$ were calculated by inversion of the imposed evaporation equation:

$G_{\mathrm{s}}=\frac{E_{\mathrm{p}} P}{D}$

where $E_{\mathrm{p}}\left(\mathrm{mol} \mathrm{m} \mathrm{m}^{-2} \mathrm{~s}^{-1}\right)$ is the transpiration rate per $\mathrm{m}^{2}$ of soil (deduced from sap flow records and tree spacing), $P$ is atmospheric pressure $(\mathrm{kPa})$ and $D$ is vapour pressure deficit $(\mathrm{kPa})$.

Determination of hydraulic resistances

Apparent resistance $\left(R, \mathrm{MPa} \mathrm{m}^{2} \mathrm{~s} \mathrm{~mol}^{-1}\right)$ of the whole soil-plant continuum was deduced using Ohm`s law analogy from transpiration rate normalized by cross-sectional trunk area $\left(Q_{\mathrm{n}}\right.$, mol m $\left.\mathrm{m}^{-2} \mathrm{~s}^{-1}\right)$ and water potential gradient at midday in MPa:

$R=\frac{\left(\Psi_{\text {soil }}-\Psi\right)}{Q_{\mathrm{n}}}$ 
where predawn shoot $\Psi$ was used as a surrogate of $\Psi_{\text {soil }}$ under the assumption that the former had equilibrated with the latter by that time (Dichio et al. 2013). On the other hand, $Q_{\mathrm{n}}$ measurements were used as estimates of transpiration. Similarly, apparent $R_{\text {root }}\left(\mathrm{MPa} \mathrm{m}^{2} \mathrm{~s} \mathrm{~mol}^{-1}\right)$ was computed as:

$R_{\text {root }}=\frac{\left(\Psi_{\text {soil }}-\Psi_{\text {trunk }}\right)}{Q_{\mathrm{n}}}$

where $\Psi_{\text {trunk }}$ values were taken from the midday $\Psi$ measurements in non-transpiring shoots directly attached to trunks.

\section{$\underline{\text { Water balance }}$}

A monthly water balance was applied to assess the occurrence of drought stress during the experiments. Changes in soil water content $(S W C)$ were calculated as:

$\Delta S W C=P_{\text {eff }}+I-E T$

where $P_{\text {eff }}$ is effective precipitation, $\mathrm{I}$ is the amount of irrigation applied and ET represents the orchard evapotranspiration. The first was calculated using the U.S. Bureau of Reclamation method from monthly rainfall values recorded by the meteorological station while the approach of Orgaz et al. (2006) was applied to estimate the later. The calculations were performed from January 2011 to the end of the experiments (May 2013) assuming that our soil was in the upper limit in the former. Such assumption was justified by the huge amount of rainfall recorded in December 2010 (> $300 \mathrm{~mm})$.

Once $S W C$ was computed, it was expressed in relative terms for each month as:

$R S W C=\frac{S W C-S W C_{\mathrm{u}}}{S W C_{\mathrm{u}}-S W C_{\mathrm{l}}}$

with $S W C_{\mathrm{u}}$ and $S W C_{1}$ being the soil water content in the upper and lower limit, respectively.

$\underline{\text { Statistics }}$

The statistical treatment of the data was performed with the Statistix program (Statistix 9 for Windows, Analytical Software, Tallahassee, FL, USA). The occurrence of significant variations in $\Psi, Q_{\mathrm{n}}$ and R along each measurement season was explored through a conventional analysis of variance (ANOVA), using the LSD test at $\mathrm{P}<0.05$ for mean comparisons. For those cases in which the assumptions of ANOVA could not be fulfilled, the Kruskal-Wallis test was employed. 


\section{Results}

The two winters showed contrasting meteorological conditions. The first one (2011-2012, Fig. 1A) was particularly dry, with $189 \mathrm{~mm}$ of rainfall mainly concentrated in the beginning and end of the NovemberApril period. Mean temperature was $10.7^{\circ} \mathrm{C}$ and up to 27 days with minimum temperatures below $0{ }^{\circ} \mathrm{C}$ were recorded for the same period (18 of these days on February). By contrast, the winter 2012-2013 was characterized by abundant and more uniformly-distributed precipitation and warmer temperatures with $760 \mathrm{~mm}$ of rainfall, $11.9^{\circ} \mathrm{C}$ of mean temperature and only 6 days with frost in the November-April period (Fig. 1B).

The evaporative demand was rather low for both winters as indicated by the course of midday $D$ presented in Figure 2A-B. In this regard, marked differences between years were only evident by March. Values of midday $D$ were lower in 2013, probably due to the abundant rainfall events recorded that month (Fig. 1B). Figure 2A-B also illustrates the results of the water balance by showing the values of $R S W C$ at the beginning of each month. In general, high values were estimated throughout the two seasons, with RSWC remaining above 0.60 most of the time. Lower values were estimated only by 1-March-2012 $(R S W C=0.45)$ and 1-Apr-2012 $(R S W C=0.54)$.

The courses of predawn and midday $\Psi$ during both 2011-2012 and 2012-2013 winters are shown in Figure 2C-D. As compared to spring values (March 2012, April 2013), midday $\Psi$ was significantly lower in the beginning of both winters (December-January), clearly below -2 MPa. In fact, values lower than -3 MPa were reached in the first season. Such low winter midday $\Psi$ was not apparently accompanied by decreases in predawn $\Psi$. In fact, it remained $>-0.35 \mathrm{MPa}$ for both the whole experimental period in 20122013 and for the period between November and January in the first winter. Rather more negative predawn $\Psi$ were measured in February 2012 (-0.97 MPa) and March 2012 (-0.49 MPa), which was in accordance with the aforementioned trends of RSWC. In the former case, the low predawn $\Psi$ might also be indirectly associated with the particularly low temperatures at the time of the measurements (air temperature was $\left.1.7^{\circ} \mathrm{C}\right)$.

Both midday $Q_{\mathrm{n}}$ (Fig. 2E-F) and $G_{\mathrm{s}}$ (Fig. 2G-H) were also lower in the central and colder period of the winter, when $D$ was low (Fig. 2A-B). For both $Q_{\mathrm{n}}$ and $G_{\mathrm{s}}$, the transition from the low winter values to the 
high ones in spring was found to occur earlier in 2012-2013 than in 2011-2012. The final decrease in $G_{\mathrm{s}}$ observed in 2012-2013 (Fig. 2H) coincided with a period of high temperatures (Fig. 1B) and evaporative demand (note also the final rise in $D$ in Fig. 2B).

The courses of midday $Q_{\mathrm{n}}$, midday $\Psi$ and predawn $\Psi$ resulted in a peaked pattern for the computed $R$ (Fig. 2I and 2J, bottom panels). For both years, maximum values occurred in December and January but the maximum averaged values measured in 2011-2012 (5.9 $\left.\mathrm{MPa} \mathrm{m}^{2} \mathrm{~s} \mathrm{~mol}^{-1}\right)$ were several-fold greater than those found in 2012-2013 (1.78 $\left.\mathrm{MPa} \mathrm{m}^{2} \mathrm{~s} \mathrm{~mol}^{-1}\right)$. Interestingly, these maximum values did not perfectly coincide with the coldest periods of winter revealing that the time series of air and soil temperature were not clearly in phase with those of $R$ (see Figures 1 and 5). For instance, by mid February both $R$ and midday $\Psi$ decreased to values similar to those determined in late November despite the temperatures in the former month being similar or colder (especially in 2012) than those of December or January (Fig. 1A and 1B), when $R$ was the highest. Likewise, the periods with low predawn $\Psi$ (Fig. 2C) and low RSWC (Fig. 2A) in February-March 2012 were not in phase with the peak of $R$ recorded earlier (December-January) that winter.

Concerning the variability among individuals shown by the error bars in Fig. 2, trees behaved in a similar way in terms of predawn and midday $\Psi$ (average $\mathrm{CV}$ close to $10 \%$ in all cases) while differences in $Q_{\mathrm{n}}$ were slightly higher (average CV of $22 \%$ in 2011-2012 and $17 \%$ in 2012-2013). Obviously, the variability in both $\Psi$ and $Q_{\mathrm{n}}$ led to large differences in $R$ between individuals (CV=64\% in 2011-2012 and $20 \%$ in 2012-2013), but the differences between winter and spring values were still significant.

The higher $R$ values in winter were also evident analyzing the diurnal dynamics of $\Psi$ conducted in the 2012-2013 season (Fig. 3). Computing $R$ as the slope of the relationships $Q_{\mathrm{n}}$ vs. $\Psi$ yielded similar values to those calculated from midday measurements and followed the same pattern, with the slope being the steepest in absolute terms for December $22^{\text {nd }}\left(1.74 \mathrm{MPa} \mathrm{m}^{2} \mathrm{~s} \mathrm{~mol}^{-1}\right)$ and the lowest for April $12^{\text {th }}(0.23$ $\left.\mathrm{MPa} \mathrm{m} \mathrm{s} \mathrm{mol}^{-1}\right)$. Moreover, significant correlations $(\mathrm{P}<0.01)$ and good fits $\left(\mathrm{r}^{2}>0.90\right)$ between $Q_{\mathrm{n}}$ and $\Psi$ were always found independently of both the tree and the date.

Figure 4 presents the diurnal trends of $\Psi, Q_{\mathrm{n}}$ and $G_{\mathrm{s}}$ for two dates, one representing early winter (29 January 2013, when the estimates of $R$ were high) and the other spring conditions (12 April 2013, when low values of $R$ were deduced). Although predawn $\Psi$ values (the first point in Fig. 4A) were high (> -0.3 $\mathrm{MPa}$ ) and similar between the two compared dates, a sharp decline in $\Psi$ was observed for the winter date 
in relation to that of spring. In terms of $Q_{\mathrm{n}}$, lower values were found in winter throughout the daytime, but they may be related to the lower evaporative demand in that date (the daytime average $D$ was $0.57 \mathrm{kPa}$ in the winter date and $1.03 \mathrm{kPa}$ in the spring one). Finally, the trends of $G_{\mathrm{s}}$ differed between the two dates in early morning but were rather similar in the afternoon.

The measurements of $\Psi$ in covered shoots followed the same trends as those of sun-exposed shoots in both seasons with lower values in early winter than at the end of the measurement periods. As a consequence, the computed $R_{\text {root }}$ (Eq. 4) exhibited peaked patterns similar to those of $R$, but reaching slightly lower values throughout the two measurement seasons (Fig. 5). In relation to $R_{\text {root }}$, the trunk to shoot hydraulic resistance (i.e. the difference between $R$ and $R_{\text {root }}$ ) presented little seasonal variations, despite showing slightly higher values by December in both years. Comparing the maximum winter values with the minimum spring ones, relative changes in $R(\Delta R)$ of 20.8 -fold and 6.7 -fold were registered while those of $R_{\text {root }}$ yielded 19.2-fold and 9.2-fold for 2011-2012 and 2012-2013 seasons, respectively. By contrast, the estimated seasonal changes in root sap $\eta(\Delta \eta)$ in the second year were of a lesser magnitude, as illustrated in Figure 6. For instance, comparing the same pairs of dates $\eta$ decreased from $1.3210^{-9}$ in winter to $1.0210^{-9} \mathrm{MPa} \mathrm{s}$ in spring. Therefore, the estimated $\Delta \eta$ (i.e. 1.29 -fold changes using again spring values as the reference) was rather low as compared to those of $\Delta R_{\text {root }}$ (Fig. 5).

\section{Discussion}

The results of the present work show that low winter temperatures result in a disturbance of water relations in mature olive trees. Regardless of the year, such disturbance was particularly evident in early winter (December-January). By that time, our measurements of midday $\Psi$ revealed lower values (below $2 \mathrm{MPa}$, Fig. 2C-D) than those usually found in well irrigated olive cv. Arbequina trees in summer (down to $-1.5 \mathrm{MPa}$ according to Iniesta et al. 2009), even though evaporative demand is substantially lower in winter. By contrast, the values of $R S W C$ estimated from the water balance were fairly high $(>0.6$ in December-January, Fig. 2A-B) in relation to the critical threshold from which a water stress-induced decrease in transpiration is expected for olive trees (0.45 according to Allen et al. 1998). It is noteworthy that this threshold $R S W C$ is reported for conditions of high evaporative demand and hence, its value is expected to be even lower in winter (Allen et al. 1998). In the same line, the predawn $\Psi$ measurements yielded high values (> -0.35 MPa, Fig. 2C-D) in December-January, which were comparable to those 
found by other authors in well-irrigated olive trees in summer (Angelopoulus et al. 1996; Tognetti et al. 2009). Lower values of $R S W C(0.45)$ and predawn $\Psi(-0.95 \mathrm{MPa})$ were also observed in February 2012 , probably as a consequence of the scant precipitation recorded that winter (Fig. 1A), but midday $\Psi$ was not as low as in the precedent period (Fig. 2C). All this body of evidence indicates that the observed disturbance of water relations occurred under non-limiting soil water conditions and can be mainly attributed to the effect of early winter chilling temperatures.

Our observations of low midday $\Psi$ may indicate tissue dehydration which would be to some extent in consonance with the experiments of Charrier and Ameglio (2011) and Charrier et al. (2013). These authors worked with two-years-old walnut trees and found that the low temperatures of winter induced a decrease in stem water content in relation to cold-deprived plants. Earlier reports about chilling responses in potted plants (e.g. Kramer 1940; Running and Reid 1980) have suggested that the alteration in water relations is triggered by changes in $R$ leading to imbalances between transpiration and water uptake. Such circumstance was also observed in our study (Fig. 2I-J). Apart from that and agreeing with the observations of Pavel and Fereres (1998) in 1-year old olive trees growing in pots, our measurements provided evidence that the $\Delta R$ took place mainly in the soil-root-trunk water pathway (Fig. 5). But, what was the actual cause of changes in $R_{\text {root }}$ in winter?

The literature shows that $\Delta \eta$ is one of the main factors triggering $\Delta R_{\text {root }}$ under chilling stress conditions (Kramer 1940; Cochard et al. 2000; Norisada et al. 2005). In this study, midday soil temperatures and the concomitant estimated root sap $\eta$ differed little among the measurement dates of the second season (maximum $\Delta \eta$ around 1.4-fold; Fig. 6) as compared to $R_{\text {root }}\left(\Delta R_{\text {root }}\right.$ of 9.2-fold; Fig. 5). Therefore, our results suggest that the contribution of $\eta$ to either $\Delta R$ or $\Delta R_{\text {root }}$ was negligible, which is in agreement with the findings of other authors (Ameglio et al. 1990; Pavel and Fereres 1998; Murai-Hatano et al. 2008; see also Table 1). This analysis and its conclusions may be criticized because of the shallow depth at which the soil temperature measurements shown in Figure 6 were conducted $(75 \mathrm{~mm})$, which does not represent the whole root system temperature. Nevertheless, our results are unlikely to underestimate the role of $\eta$ because soil temperature variations (and hence those of $\eta$ ) are increasingly mitigated at greater soil depths. Furthermore, the contribution of $\eta$ to the observed $\Delta R$ should be of minor importance from a theoretical point of view: in a hypothetical and exaggerated situation in which root sap temperature changed from $0{ }^{\circ} \mathrm{C}$ in winter to $30^{\circ} \mathrm{C}$ in spring, the winter value of $\eta$ would hardly be twice the spring one, which is still far from the observed 11.4 -fold $\Delta R_{\text {root }}$. 
Leaving aside the contribution of $\eta$, the most widespread hypothesis in the literature explaining the reported chilling-induced $\Delta R_{\text {root }}$ lies in biological and metabolic changes in the radial water pathway from the soil-root interface to the xylem. Those changes can be associated with either membrane permeability, through aquaporin activity (Murai-Hatano et al. 2008; Aroca et al. 2011) and/or suberin deposition in the root endodermis (Lee et al. 2005). The experiments of Pavel and Fereres (1998) in young olive trees showed $\Delta R_{\text {root }}$ occurring in less than three days, sustaining the hypothesis of reduced membrane permeability as suberin deposition should take longer (Enstone and Peterson 1997). Nevertheless, they found much lower $\Delta R$ than those presented in this work (Table 1) which may point to additional factors (beyond both the cellular level and the short term) playing a role in our conditions. In this regard, the results observed in this study may be associated with alterations in root growth dynamics as they are affected by temperature as well (Kramer 1940; Wan et al. 1999; Pregitzer et al. 2000). In other words, low soil temperatures in winter may hinder root proliferation limiting the amount of absorbing roots, which, in turn, would lead to an increase in $R_{\text {root }}$. This hypothesis is to some extent supported by the observations of Fernández et al. (1992), who, working with mature olive trees subjected to different irrigation treatments, found decreases in root density of variable magnitude (depending on the treatment and point of measurement) during the winter months. As a final remark, cavitation in root xylem vessels might have played a role in the observed $\Delta R_{\text {root }}$ but there seem to be few arguments to support this explanation under our experimental conditions. On the one hand, freeze-thaw-induced embolisms were unlikely because periods of frost (Fig. 1) were infrequent, mild (air temperatures not much below $0{ }^{\circ} \mathrm{C}$ ), short in time (hours), and, above all, they should have affected distal shoots and branches rather than trunks or roots, whose temperature must be closer to that of the soil. On the other hand, one could argue that the low $\Psi$ measured in winter might have originated cavitations in the large vessels of main roots and trunks, but it should also have occurred in main branches and again translated into increases in the trunk to shoot $R$ (i.e. the difference between $R$ and $R_{\text {root }}$ in Fig. 5) which were not clearly observed.

An interesting result of the present study is the huge variability found in the degree of disturbance of water relations between winters. Thus, values of both minimum midday $\Psi$ and $\Delta R$ were significantly lower and higher, respectively, in December 2011 - January 2012 than for the same months of 2012-2013 (Fig. 2 and 5). It should be stressed again that such differences appeared under non-limiting soil water conditions as evidenced by both the high $R S W C$ and high predawn $\Psi$ recorded for both years (rather low RSWC and predawn $\Psi$ were evident by February 2012, but it did not correspond to the period with the 
highest $\Delta R$; Fig. 2). Apart from that, the differences between winters in the December/January temperatures were not very marked (on average the second winter was $1.4^{\circ} \mathrm{C}$ warmer in DecemberJanuary, Fig. 1), which also points to a minor role of $\eta$ as a cause for such observations. However, it is unknown whether such small difference in temperature leads to an equally small difference in membrane permeability or not. In this regard, many studies (e.g. Running and Reid 1980; Ameglio et al. 1990) have shown that $R_{\text {root }}$ increases exponentially when root temperature falls below a threshold. Therefore, under certain circumstances, a small temperature decrease might result in a large $\Delta R_{\text {root }}$. Unfortunately, the relationship between $R_{\text {root }}$ and root temperature is unknown in the case of olive, so it is not possible to quantify if the temperature differences between winters lead to significant differences in $R_{\text {root }}$ Finally, a reasonable hypothesis linking the inter-year differences in $\Delta R_{\text {root }}$ with the alternate bearing behavior of olive trees can also be formulated. The higher fruit load in the first year $\left(16.5 \mathrm{t} \mathrm{ha} \mathrm{h}^{-1}\right.$ in terms of fresh weight) could have resulted in lower carbon availability for root turnover during winter, leading to the development of higher $R_{\text {root }}$ and lower $\Psi$ in relation to the second one (when the yield was lower, 5.2 t ha $^{-}$ $\left.{ }^{1}\right)$.

Regardless of the year being considered, our results revealed higher $\Delta R$ than those previously reported (Table 1). The fact that our estimated $\Delta R$ were higher than those reported by Pavel and Fereres (1998) in young olive plants suggests that the exposure to low temperatures might cause different effects between potted and field olive trees and underline that the reported responses with chilled young plants growing in controlled conditions are not necessarily the same that take place under natural conditions. Such discrepancies might be ascribed to differences in structural patterns (e.g. root architecture) or in the duration and conditions of experiments. For instance, Pavel and Fereres (1998) measured $\Delta R$ in less than three days after trees were exposed to low soil temperatures, so long-term responses to chilling such as a decrease in the amount of absorbing roots, and suberization of endodermal cells are not expected to be captured. Moreover, additional factors typically absent in young trees but present in our experimental conditions (e.g. presence of fruits) might also play a role.

Another intriguing observation arises when the patterns of $R$ or $R_{\text {root }}$ (Fig. 5) are compared with those of air or soil temperatures (Fig. 1 and 6). Under similar temperature conditions, both $R$ and $R_{\text {root }}$ decreased significantly by February in relation to December-January. This phenomenon may be associated with acclimation processes allowing the trees to cope better with the low temperatures of the end of winter. In this context, it is well known that certain exposure to low temperatures provides protection against freeze 
and chilling stresses through changes in metabolism, most of them related to membrane lipids and proteins, and possibly including aquaporins (Fennel and Markhart 1998; Ahamed et al. 2012).

Finally, this study shows that the water relations in mature olive trees are altered during winter through increased $R$, but it remains unclear if such alterations can affect canopy conductance and gas exchange. Figure 2G-H shows a decline in $G_{\mathrm{s}}$ in winter which apparently supports the hypothesis of the direct effects on stomatal aperture. Nevertheless, the low winter $G_{\mathrm{s}}$ found in this work may be related to different factors. For instance, photosynthesis rates could be limited by the low temperatures of winter inducing stomata to close, which would concur with the delay in the recovery of $G_{\mathrm{s}}$ in 2011-2012 versus 2012-2013.

\section{Conclusions}

This study show for the first time that winter low temperatures lead to a disturbance of water relations in field olive trees. Chilling induced an increase in $R$ that resulted in midday $\Psi$ falling to lower values than those expected for well-irrigated trees in summer, despite evaporative demand being substantially lower during our experiments. Apparently, measurements of predawn $\Psi$ and estimates of $R S W C$ indicated that this phenomenon took place under non-limiting conditions of soil water availability. Besides that, our estimated chilling-induced increases in either $R$ were higher than those previously reported for young potted trees growing under controlled conditions. This, along with additional findings, such as differences in the chilling effects between winters or the lags between the peaks of $R$ and temperature suggest that the phenomenon is more complex and involves a greater number of factors in the case of mature trees.

\section{Acknowledgements}

This work was funded by the Spanish Ministry of Science and Innovation (MICINN, project AGL-201020766) and European Regional Development Fund (ERDF). We thank the Spanish Research Council (CSIC) predoctoral JAE program and the aforementioned project for providing the Ph.D. scholarship granted to the first and second author, respectively. We are grateful both to Ms Julie Newton for helpful assistance with language editing and to Mr Rafael del Río, Mr Ignacio Calatrava and Mr José Luis Vazquez for the excellent technical support provided. 


\section{References}

Ahamed A, Murai-Hatano M, Ishikawa-Sakurai J, Hayashi H, Kawamura Y, Uemura M (2012) Cold stress-induced acclimation in rice is mediated by root-specific aquaporins. Plant cell Physiol 53: 14451456.

Allen RG, Pereira JS, Raes D, Smith M (1998) Crop evapotranspiration: guidelines for computing crop water requirements. FAO Irrigation and Drainage Paper, 56. Food and Agriculture Organization of the United Nations, Rome 300 pp.

Améglio T, Morizet J, Cruiziat P, Martignac M (1990) The effects of root temperature on water flux, potential and root resistance in sunflower. Agronomie 10: 331-340.

Angelopoulos K, Dichio B, Xiloyannis C (1996) Inhibition of photosynthesis in olive trees (Olea europaea L.) during water stress and rewatering. J Exp Bot 47:1093-1100.

Aroca R, Porcel R, Ruiz-Lozano JM (2011). Regulation of root water uptake under abiotic stress conditions. J Exp Bot 63: 43-57.

Aroca R, Tognoni F, Irigoyen JJ, Sánchez-Díaz M, Pardossi A (2001) Different root low temperature response of two maize genotypes differing in chilling sensitivity. Plant Physiol Bioch 39: 1067-1073.

Bloom AJ, Zwieniecki MA, Passioura JB, Randall LB, Holbrook NM, Clair DAST (2004) Water relations under root chilling in a sensitive and tolerant tomato species. Plant Cell Environ 27: 971-979.

Boughalleb F, Hajlaoui H (2011) Physiological and anatomical changes induced by drought in two olive cultivars (cv Zalmati and Chemlali). Acta Physiol Plant 33:53-65.

Charrier G, Améglio T (2011) The timing of leaf fall affects cold acclimation by interactions with air temperature through water and carbohydrate contents. Environ Exp Bot 72: 351-357.

Charrier G, Poirier M, Bonhomme M, Lacointe A, Améglio T (2013) Frost hardiness in walnut trees (Juglans regia L.): How to link physiology and modeling? Tree Physiol 33: 1229-1241. 
Cochard H, Martin R, Gross P, Bogeat-Triboulot MB (2000) Temperature effects on hydraulic conductance and water relations of Quercus robur L. J Exp Bot 51: 1255-1259.

Connor DJ (2005) Adaptation of olive (Olea europaea L.) to water-limited environments. Aust J Agr Res 56: 1181-1189.

Dichio B, Montanaro G, Sofo A, Xiloyannis C (2013) Stem and whole-hydraulics in olive (Olea europaea) and kiwifruit (Actinidia deliciosa). Trees 27: 183-191.

Enstone DE, Peterson CA (1997) Suberin deposition and band plasmolysis in the corn (Zea mays L.) root exodermis. Can J Bot 75: 1188-1199.

Fennell A, Markhart AH (1998) Rapid acclimation of root hydraulic conductivity to low temperature. J Exp Bot 49: 879-884.

Fernández JE, Cuevas MV (2010) Irrigation scheduling from stem diameter variations: a review. Agr Forest Meteorol 150: 135-151.

Fernández JE, Moreno F, Girón IF, Blázquez OM (1997) Stomatal control of water use in olive tree leaves. Plant Soil 190: 179-192.

Fernández JE, Moreno F, Martin-Aranda J, Fereres E (1992) Olive-tree root dynamics under different soil water regimes. Agr Med Vol 122:225-235.

Fernández JE, Moreno F, Martín-Palomo MJ, Cuevas MV, Torres-Ruiz JM, Moriana A (2011) Combining sap flow and trunk diameter measurements to assess water needs in mature olive orchards. Environ Exp Bot 72: 330-338.

Hertel A, Steudle E (1997) The function of water channels in Chara: The temperature dependence of water and solute flows provide evidence for composite membrane transport and for a slippage of small organic solutes across water channels. Planta 202: 324-335.

Iniesta F, Testi L, Orgaz F, Villalobos FJ (2009). The effects of regulated and continuous deficit irrigation on the water use, growth and yield of olive trees. Eur J Agron 30: 258-265.

Kramer PJ (1940) Root resistance as a cause of decreased water absorption by plants at low temperatures. Plant Physiol 15: 63-79. 
Kramer PJ (1942) Species differences with respect to water absorption at low soil temperatures. Am J Bot 29: $828-832$.

Lee SH, Chung GC, Steudle E (2005) Gating of aquaporins by low temperature in roots of chillingsensitive cucumber and chilling-tolerant figleaf gourd. J Exp Bot 56: 985-995.

López-Bernal A, Alcantara E, Testi L, Villalobos FJ (2010) Spatial sap flow and xylem anatomical characteristics in olive trees under different irrigation regimes. Tree Physiol 30: 1536-1544.

López-Bernal A, Testi L, Villalobos FJ (2012) Using the compensated heat pulse method to monitor trends in stem water content in standing trees. Tree Physiol 32: 1420-1429.

Moriana A, Orgaz F, Pastor M, Fereres E (2003) Yield responses of a mature olive orchard to water deficits. J Am Soc Hortic Sci 128: 425-431.

Murai-Hatano M, Kuwagata T, Sakurai J, Nonami H, Ahmed A, Nagasuga K, Matsunami T, Fukushi K, Maeshima M, Okada M (2008) Effect of low root temperature on hydraulic conductivity of rice plants and the possible role of aquaporins. Plant Cell Physiol 49: 1294-1305.

Norisada M, Hara M, Yagi H, Tange T (2005) Root temperature drives winter acclimation of shoot water relations in Cryptomeria japonica seedlings. Tree Physiol 25: 1447-1455.

Orgaz F, Testi L, Villalobos FJ, Fereres E (2006) Water requirements of olive orchards-II: determination of crop coefficients for irrigation scheduling. Irrigation Sci 24, 77-84.

Passioura JB (2006) The perils of pot experiments. Funct Plant Biol 33, 1075-1079.

Pavel EW, Fereres E (1998) Low soil temperatures induce water deficits in olive (Olea europaea) trees. Physiol plantarum 104: 525-538.

Pérez-López D, Gijón MC, Mariño J, Moriana A (2010) Water relation response to soil chilling of six olive (Olea europaea L.) cultivars with different frost resistance. Span J Agric Res 8: 780-789.

Pregitzer KS, King JS, Burton AJ, Brown SE (2000) Responses of tree fine roots to temperature. New Phytol 147: 105-115. 
Roderick ML, Berry SL (2001) Linking wood density with tree growth and environment: a theoretical analysis based on the motion of water. New Phytol 149: 473-485.

Running SW, Reid CP (1980) Soil temperature influences on root resistance of Pinus contorta seedlings. Plant Physiol 65: 635-640.

Steudle E (2000) Water uptake by roots: effects of water deficit. J Exp Bot 51:1531-1542.

Swanson RH, Whitfield WA (1981) A numerical analysis of heat pulse velocity theory and practice. J Exp Bot 32: 221-239.

Testi L, Villalobos FJ (2009) New approach for measuring low sap velocities in trees. Agr Forest Meteorol 149: 730-734.

Testi L, Villalobos FJ, Orgaz F (2004) Evapotranspiration of a young irrigated olive orchard in southern Spain. Agr Forest Meteorol 121: 1-18.

Testi L, Villalobos FJ, Orgaz F, Fereres E (2006) Water requirements of olive orchards: I simulation of daily evapotranspiration for scenario analysis. Irrigation Sci 24: 69-76.

Tognetti R, Giovannelli A, Lavini A, Morelli G, Fragnito F, d'Andria R (2009) Assessing environmental controls over conductances through the soil-plant-atmosphere continuum in an experimental olive tree plantation of southern Italy. Agr Forest Meteorol 149: 1229-1243.

Torres-Ruiz JM, Diaz-Espejo A, Morales-Sillero A, Martin-Palomo MJ, Mayr S, Beikircher B, Fernandez JE (2013) Shoot hydraulic characteristics, plant water status and stomatal response in olive trees under different soil water conditions. Plant Soil 373: 77-87.

Villalobos FJ, Testi L, Orgaz F, García-Tejera O, López-Bernal A, González-Dugo MV, Ballester-Lurbe C, Castel JR, Alarcón-Cabañero JJ, Nicolás-Nicolás E, Girona J, Marsal J, Fereres E (2013) Modelling canopy conductance and transpiration of fruit trees in Mediterranean areas: a simplified approach. Agric For Meteorol 171:93-103.

Wan X, Landhäusser SM, Zwiazek JJ, Lieffers VJ (1999). Root water flow and growth of aspen (Populus tremuloides) at low root temperatures. Tree Physiol 19: 879-884. 
Wan X, Zwiazek JJ, Lieffers VJ, Landhäuser SM (2001) Hydraulic conductance in aspen (Populus tremuloides) seedlings exposed to low root temperatures. Tree Physiol 21: 691-696.

Yamamoto R (1995) Dependence of water conductivity on pressure and temperature in plant stems. Biorheology 32: 421-430. 


\section{Tables}

Table 1: Maximum increases in hydraulic resistance ( $\triangle R$, in $\mathrm{n}$-folds increases) observed in the literature for woody species exposed to different temperature treatments. Equation 1 was applied to deduce the viscosity increments $(\Delta \eta$, in $\mathrm{n}$-folds). Data from the present study are presented in the last two rows allowing comparisons. Values of $\eta$ for the 2012-2013 season were estimated from midday soil temperature measurements.

es erature range

ds)

ds)

\begin{tabular}{|c|c|c|}
\hline ing and Reid (1980) & contorta & 0.0 \\
\hline and Fereres (1998) & zuropaea & 4.6 \\
\hline ard et al., (2000) ** & :us robur & 2.0 \\
\hline et al., (2001)* & us tremuloides & 5.0 \\
\hline ada et al., (2005)* & omeria japonica & 5.0 \\
\hline :xperiment (2011-2012) & zuropaea & \\
\hline :xperiment (2012-2013) & zuropaea & 10.7 \\
\hline
\end{tabular}




\section{Figures list}

Figure 1: Maximun $\left(\mathrm{T}_{\max }\right)$ and minimum $\left(\mathrm{T}_{\min }\right)$ daily temperatures and daily precipitation recorded by a meteorological station during the experiments in 2011-2012 (A) and 2012-2013 (B) winters.

Figure 2: Patterns of midday vapor pressure deficit (D; solid line) and relative soil water content $(R S W C$; dotted line with circles) (A and B), predawn (closed symbols) and midday (open symbols) stem water potentials ( $\Psi$; $\mathbf{C}$ and $\mathbf{D})$, sap flow rate normalized by cross-sectional sapwood area $\left(Q_{\mathrm{n}} ; \mathbf{E}\right.$ and $\left.\mathbf{F}\right)$, midday bulk canopy stomatal conductance $\left(G_{\mathrm{s}} ; \mathbf{G}\right.$ and $\left.\mathbf{H}\right)$, and calculated hydraulic resistances $(R ; \mathbf{I}$ and $\mathbf{J})$ for the days of measurement in both the winters 2011-2012 (left panels) and 2012-2013 (right panels). The complete time course is presented for both $G_{\mathrm{s}}$ and $D$ panels excluding those days with rainfall $>0.3 \mathrm{~mm}$. In $\Psi, Q_{\mathrm{n}}$ and $R$ panels, data are means \pm standard errors (n=5 in 2011-2012 and $\mathrm{n}=4$ in 2012-2013) of all monitored trees. Lowercase letters in panels A, B, C, D, I and J denote statistically significant $(\mathrm{P}<0.05)$ differences between dates.

Figure 3: Daily shoot water potential $(\Psi)$ as a function of sap flow rate normalized by cross-sectional sapwood area $\left(Q_{\mathrm{n}}\right)$ for the five days of measurement in the 2012-2013 season. The points represent the averaged values of the four instrumented trees for each simultaneous measurement of $Q_{\mathrm{n}}$ and $\Psi$. Vertical and horizontal error bars correspond to standard errors.

Figure 4: Diurnal course of shoot water potential ( $\Psi$; A), sap flow rate normalized by cross-sectional sapwood area $\left(Q_{\mathrm{n}} ; \mathbf{B}\right)$ and bulk canopy stomatal conductance $\left(G_{\mathrm{s}} ; \mathbf{C}\right)$ for both a winter (29-January-2013, closed symbols) and a spring date (12-April-2013, open symbols). Values are the averaged values of the four instrumented trees. Standard errors are represented by the error bars in the case of $\mathbf{A}$ and avoided in the rest for the sake of clarity.

Figure 5: Temporal variation of both the whole soil-plant continuum hydraulic resistance ( $R$; solid lines, closed symbols) and the soil-to-trunk hydraulic resistance $\left(R_{\text {root }}\right.$; dashed lines, open symbols $)$ in 2011 2012 (circles) and 2012-2013 (triangles) seasons. In the former season the results correspond to the average of the two trees in which measurements of $\Psi$ were performed in non-transpiring shoots.

Figure 6: Time course of apparent root sap viscosity ( $\eta$, solid line) and midday soil temperature (dotted line) through the 2012-2013 season. 
Fig. 1

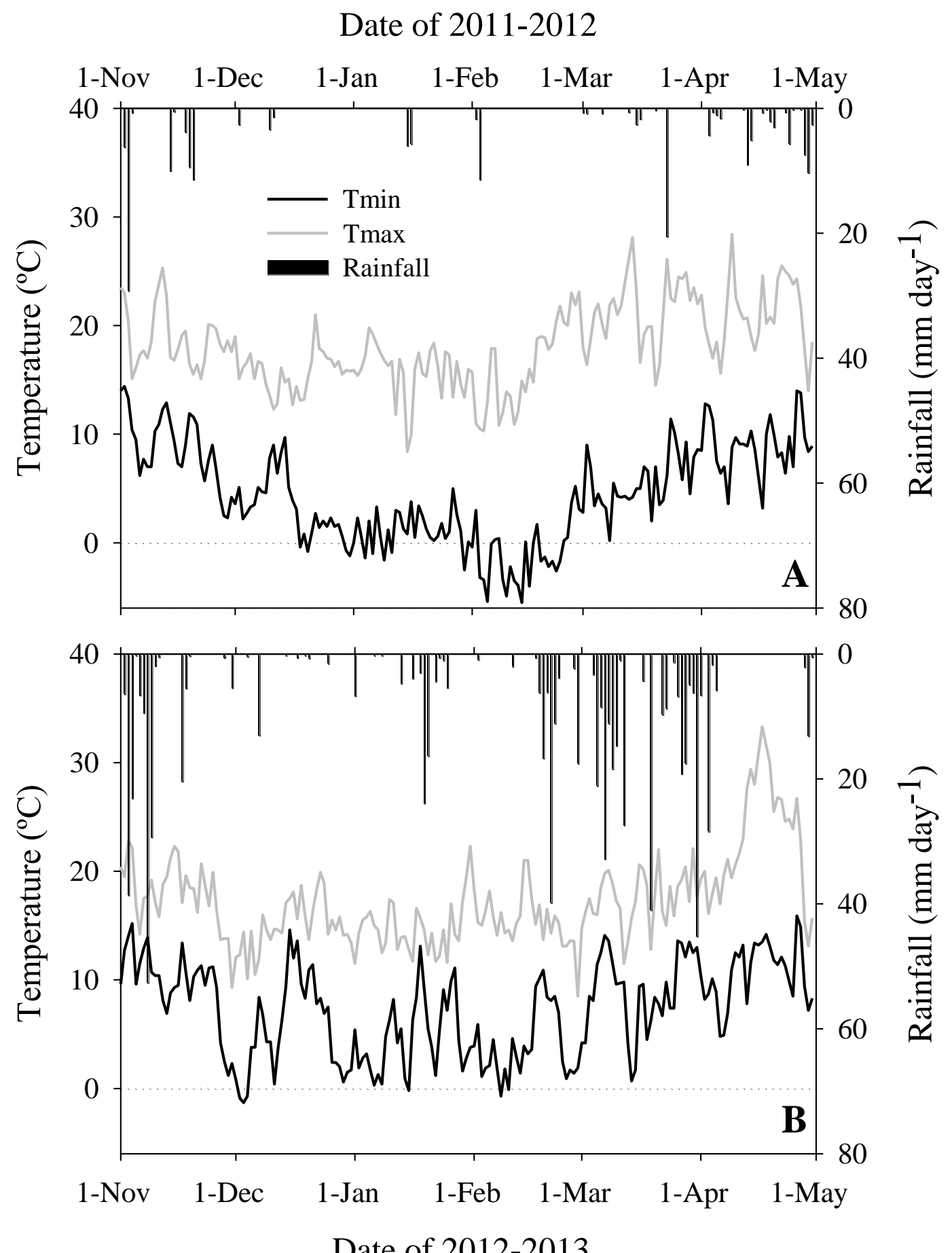


Fig. 2

Date 2011-2012
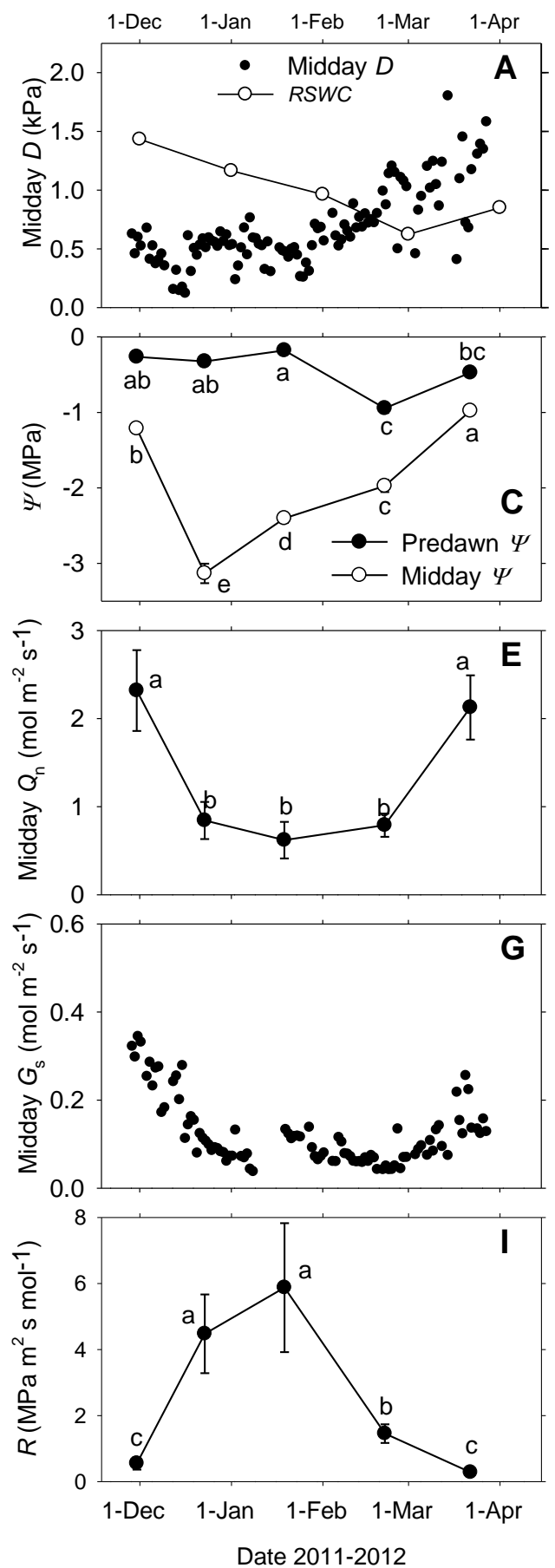

Date 2012-2013
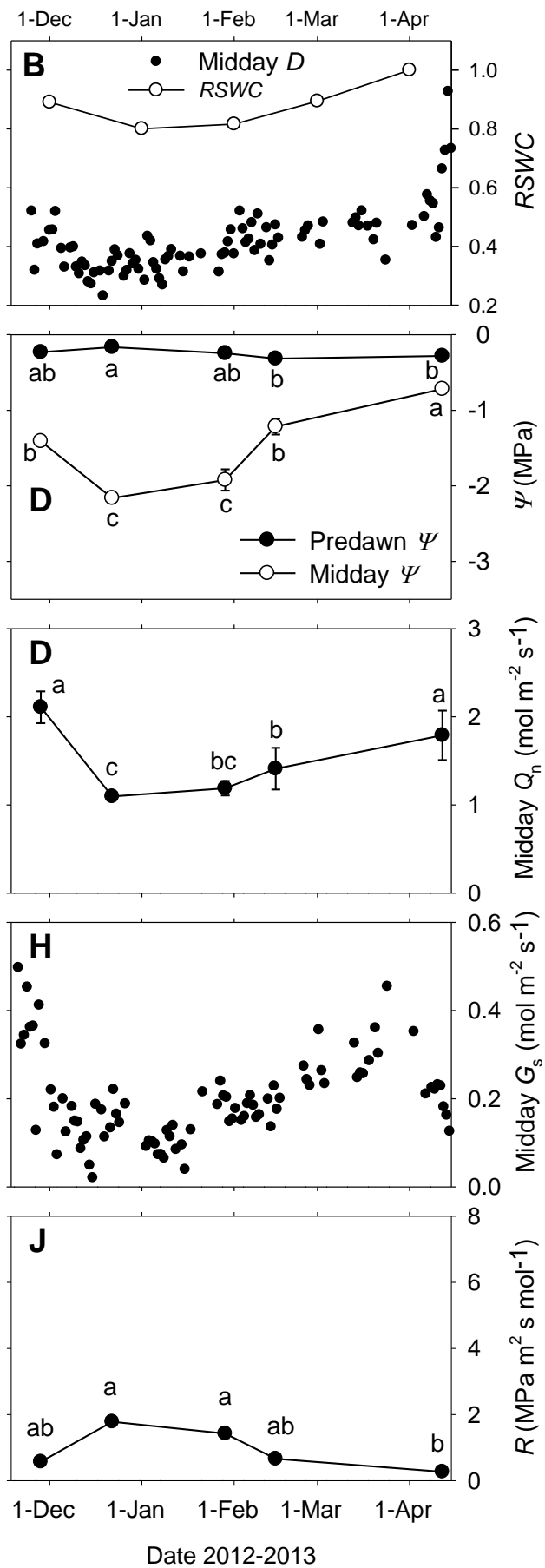
Fig. 3

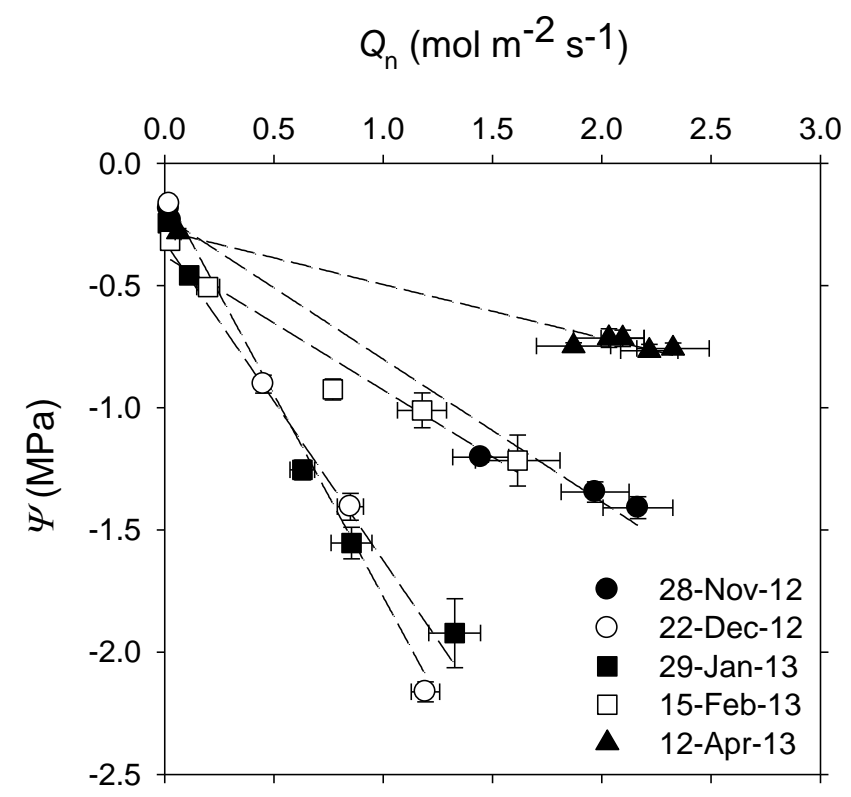


Fig. 4

\section{Hour (GMT)}

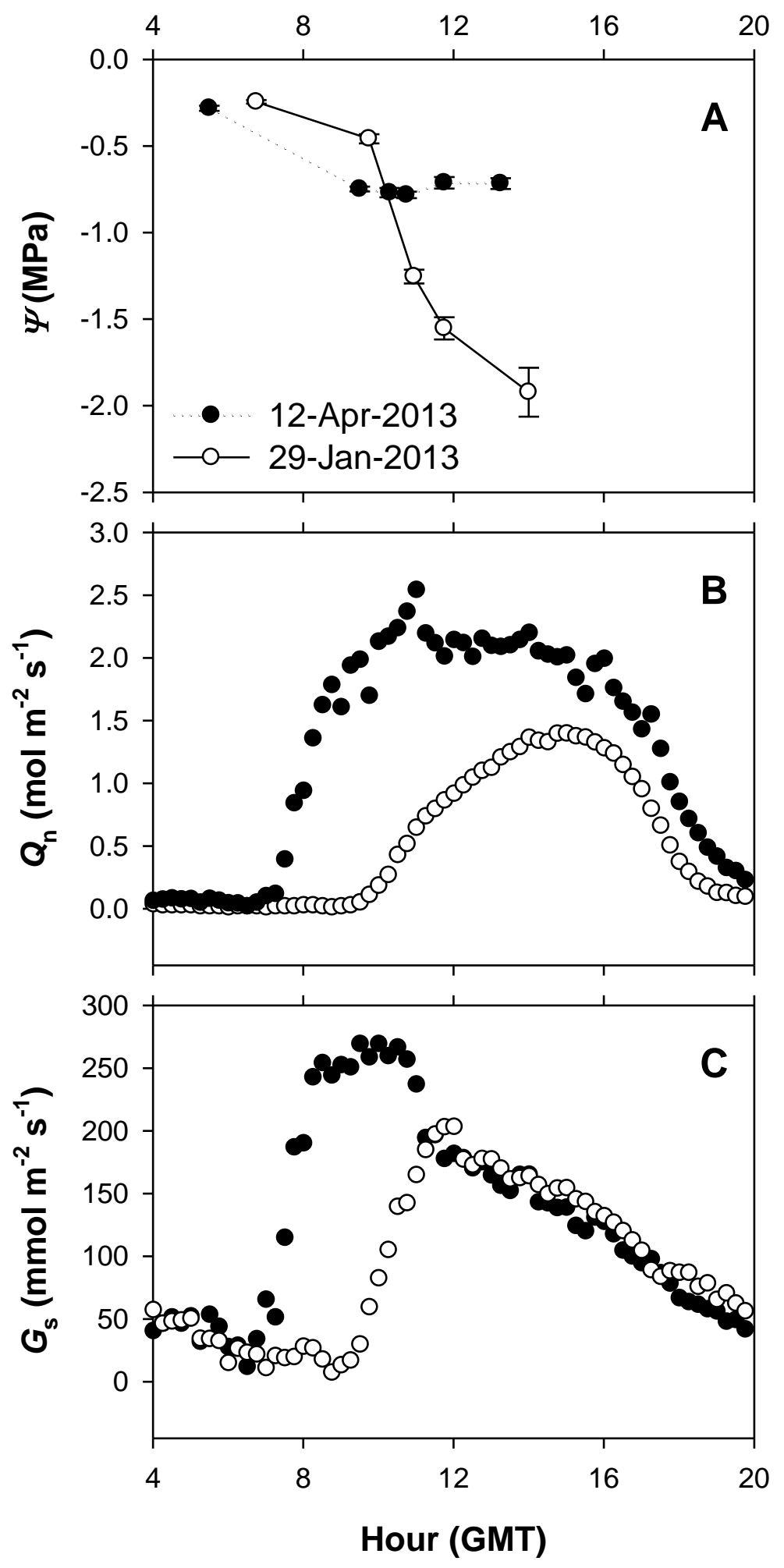


Fig. 5

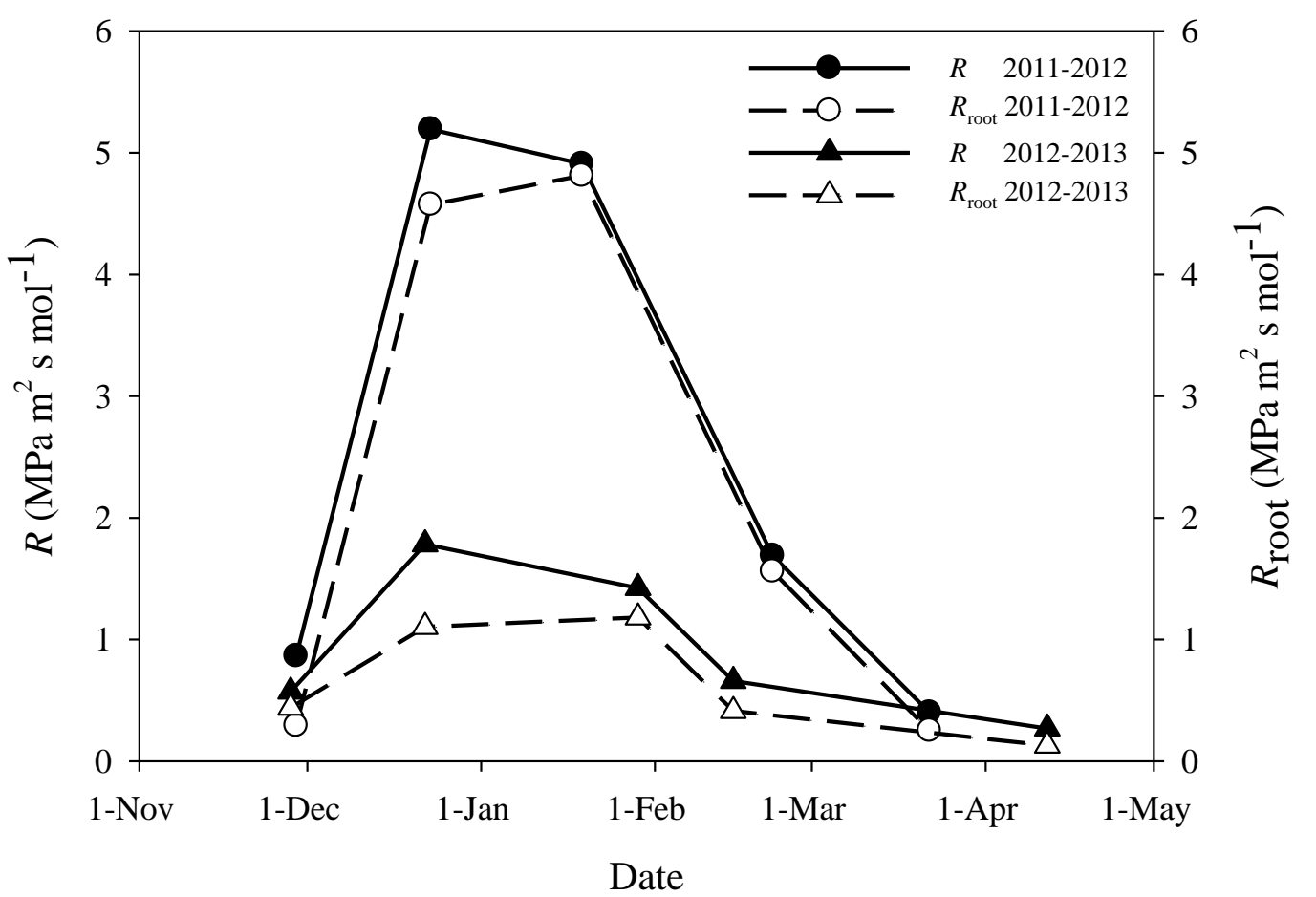


Fig. 6

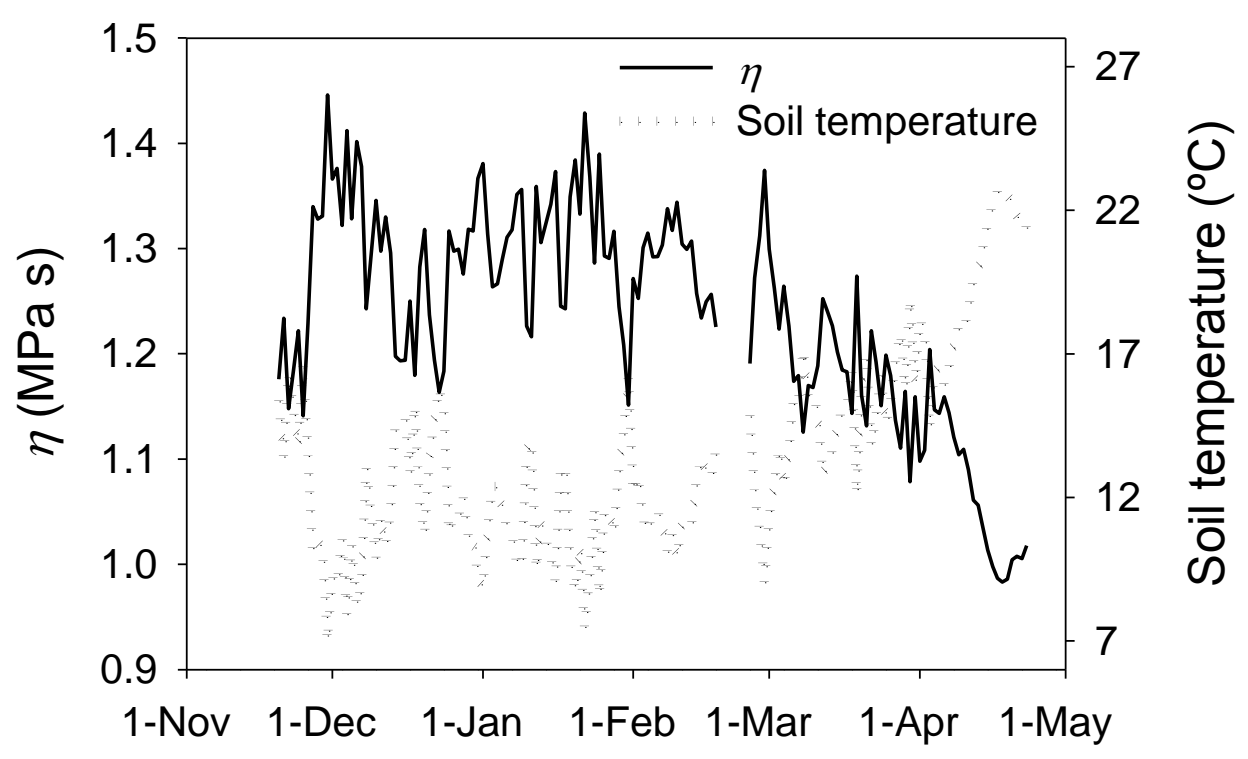

